\title{
Announcement/Chronique
}

\section{Anglo-American Idealism Conference: Call for Papers}

An international conference on all aspects of late nineteenth and early twentieth century idealist philosophy will be held from July 4-6, 1997 at Manchester College, Oxford.

There will be a number of plenary sessions with invited speakers and respondents. Speakers will include James Allard (on Bradley), Leslie Armour (on McTaggart), David Holdcroft (on Collingwood), Anthony Quinton (on Green), Timothy Sprigge (on Royce), and Geoffrey Thomas (on Bosanquet).

In addition, there will be discussion sessions based on contributed papers, submissions for which are now invited. Papers should be typed, double-spaced, and not more than twelve sides in length. It is hoped that a selection of these papers will be published after the conference; submissions, therefore, will only be accepted on condition that they have not been published elsewhere and will, if required, be made available for publication in this collection.

The initial deadline for submissions is December 31, 1996.

All inquiries, abstracts, and papers should be submitted to:

\author{
Bill Mander \\ Harris Manchester College \\ Mansfield Road \\ Oxford OX1 3TD UK
}

Tel: 01865-271028

E-mail: William.mander@manchester.oxford.ac.uk 